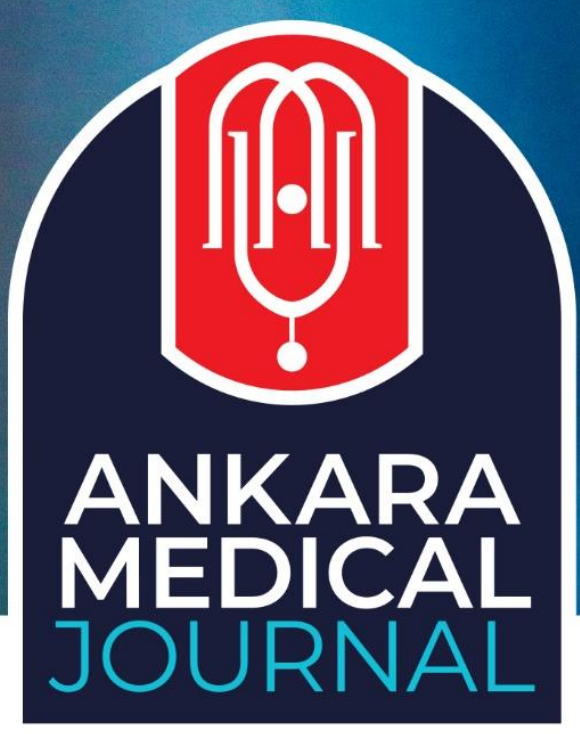

Research Article

Ankara Med J, 2020;(1):69-78 // 10 10.5505/amj.2020.79058

\title{
DEFINING THE EFFECT OF CHILD LABOUR TRAINING MODULE ON NGO'S ATTITUDES TOWARDS CHILD RIGHTS
}

ÇOCUK ISSÇILILIĞI EĞITITIM MODÜLÜNÜN SIVIL TOPLUM ÖRGÜTLERININN ÇOCUK HAKLARI TUTUMUNA ETKISIININ BELİRLENMESI

(i) Emel Demir ${ }^{1}$, (D) Erhan Yengil ${ }^{2}$

${ }^{1}$ Hatay Mustafa Kemal University, Hatay Health School, Department of Pediatrics Nursing, Hatay ${ }^{2}$ Hatay Mustafa Kemal University, Tayfur Ata Sökmen Faculty of Medicine, Department of Family

Practice, Hatay

Yazışma Adresi / Correspondence:

Emel Demir (e-mail: emelteksoz@hotmail.com)

Geliş Tarihi (Submitted): 05.08.2019 // Kabul Tarihi (Accepted): 07.03.2020

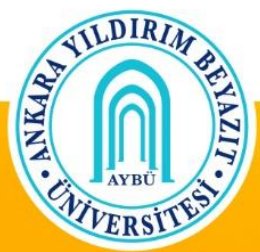

Ankara Yildırım Beyazıt University Faculty of Medicine Department of Family Medicine 


\section{Öz}

Amaç: Çocuk işçiliği çocuk hakları boyutuyla disiplinler arası çalışılması gereken bir konudur. Sivil toplum örgütlerinin Çocuk hakları konusunda eğitimi, çocuk işçiliğindeki çocukların hak kaybı ya da hakların korunması yönünde sivil toplum liderlerine önemli sorumluluk vermektedir. Araştırma sivil toplum örgütü liderlerinin çocuk hakları konusunda bilgi düzeyinin eğitim ile değișimini değerlendirmek amacıyla yapılmıștır. Materyal ve Metot: Araştırmanın tipi deneyseldir. Araştırma 2018 yılı Mart- Haziran ayları arasında 4 ayda, pilot olarak seçilen 4 ilde (Adana, Mersin, Ordu, Manisa) yapılmış, araștırmaya 123 kişi katılmıștır. Bu araștırma, Türkiye Esnaf Sanatkarlar Konfederasyonu (TESK) ve Mustafa Kemal Üniversitesi işbirliği ile UNICEF projesi kapsamında desteklenmiştir. Araştırma için liderlere, çocuk hakları ve çocuk işçiliği konusunda 4 saatlik bir eğitim verilmiştir. Bu eğitim öncesi ve sonrasında liderlere çocuk iş̧̧iliği anket formu ve çocuk hakları tutum Ölçeği uygulanmıştır. Araştırma izni MKÜ Etik kurulundan alınmıştır. Veriler SPSS 22 de analiz edilmiş, dağılım yönünden Kolmogorov-Smirnow testi ile incelenmiş sonrasında ise gruplar arası MannWhitney U testi / Kruskal Wallis testi kullanılmıştır. Eğitim öncesi ve sonrası için ise Wilcoxon testi ile değerlendirilmiş olup, p>0.05 anlamlı kabul edilmiștir.

Bulgular: Araştırma sonuçlarına göre sivil toplum liderlerinin çocuk hakları ölçeği puan ortalaması eğitim öncesi ön-test $97.52 \pm 10.95$, eğitim sonrası son-test $99.02 \pm 10.71$ olarak bulunmuștur. Çocuk haklarına yönelik eğitim öncesi ve sonrası değerler istatiksel olarak anlamlıdır ( $p=0.01)$. Eğitimin, liderlerin cinsiyeti $(E / K)$, iş pozisyonu (Başkan/Çalışan), iş yılı tecrübesi (0-11 yıl), yaş değişkenlerine göre etkisi istatiksel olarak anlamlı değildir ( $p>0.05$ ). Fakat eğitim, liderlerin eğitim durumu ve çalışmanın yapıldı̆̆ı illere göre istatiksel olarak anlamlı bulunmuştur $(\mathrm{p}<0.05)$.

Sonuç: Çocuk hakları bilgi düzeyi, sivil toplum örgütleri liderlerinin eğitim ile yükseltilebilir. Eğitimler pilot çalışmalara göre, bölgesel sonuçlar dikkate alınarak artırılmalıdır.

Anahtar Kelimeler: Çocuk hakları, çocuk işçiliği, sivil toplum liderleri.

\section{Abstract}

Objectives: Child labour is an interdisciplinary issue including the child rights dimension. Child rights training for non-governmental organizations in the means of forfeiture and keeping the rights of children gives crucial responsibility to NGO leaders. The research is done to assess the change of child rights knowledge level of NGO leaders via training.

Materials and Methods: The research is experimental and it is accomplished in 4 pilot cities (Adana, Mersin, Ordu, Manisa) in four months between March and June 2018 and 123 persons took part in it. The study is supported by a UNICEF project cooperation with The Confederation of Turkish Tradesmen and Craftsmen (CTTC) and Hatay Mustafa Kemal University (HMKU). In the frame of the research, the leaders are given a four hours of training on child rights and child labour. Child labour survey form and child rights attitude scale is applied to the leaders before and after the training. The permission for the research is got from HMKU Ethics Committee. Gathered data is analyzed by SPSS 22, examined by Kolmogorov-Smirnow test in the means of distribution and then inter-groups Mann-Whitney U test / Kruskal Wallis test is used. Wilcoxon test is used before and after the training and $p>0.05$ is accepted as meaningful.

Results: As a result of the research findings, child rights scale points average of NGO leaders are $97.52 \pm 10.95$ before training for preliminary test; and $99.02 \pm 10.71$ after training for posttest. Acquired values gathered before and after child rights training are statistically meaningful $(\mathrm{p}=0.01)$. The effect of training compared to the gender of leaders (M/F), working position (President/Worker), working experience (0-11 years), age variables is not statistically meaningful ( $p>0.05)$. On the other hand, education level of leaders is statistically meaningful depending on the cities that the research accomplished.

Conclusion: Child rights knowledge level could be increased via the training of NGO leaders. The trainings should be increased considering the regional results depending on the pilot studies.

Keywords: Child rights, child labour, non-governmental organization leaders. 


\section{Introduction}

The Convention on the Rights of the Child (CRC) supply stimulus and a gold standard which will encourage countries at all stages of development to improve life quality of children. ${ }^{1,2,3}$ The CRC is about the rights of all children that their right on health, education, an adequate standard of living, leisure and play, protection from exploitation including child labour. ${ }^{4}$ The CRC has had a remarkable impact on the position of children in society both in the Turkey and internationally.

There are currently 168 million child labourers including eighty-five million of them are engaged in hazardous work in the world. The most of child labourers' health, safety and moral development directly endanger in hazardous work.5,6 Child labourers are at risk of children rights violations in the means of childhood development. ${ }^{4}$ In countries involved child labour, many of the Rights set out in the Convention are unreal for most of children(1). The hazardous conditions of these children cause social harm and high-risk behaviors. ${ }^{7,8}$ Child labour is a violation against children, and may cause child abuse and neglect. A few studies about it have addressed an increase in high-risk behaviors in the near future.7,9,10 Another study focused on prevalence of physical abuse among domestic child labour. ${ }^{9}$ The findings of other study, showed $30 \%$ of Tehran child labourer are illiterate and some had never attended any formal educational program. ${ }^{7}$ Identification of this issue is essential because it can enable non-government employers to design work conditions carefully in order to solve the problem. Their working conditions, hours of labour, working places should be improved by the help of employer. 9,11

Professionals who are in charge of pediatric health can contribute to improve health outcomes through advocacy, policy development, research and service delivery at international level. Professionals including pediatric nurses are highly effective advocates for children rights and their interventions can be reinforcing the situation of child labourers and their families also. Pediatric nurses can, and do, advocate for and implement evidence based research and education program and they can challenge policies and practices that impact negatively on the health of children minors in their local child labour. ${ }^{12}$ The aim of the study is determination of the impact of child labour training on the attitude of children's rights of NGO's.

\section{Materials and Methods}

\section{Type of the Research, Date and Place}

The research is prospective and descriptive. It is accomplished in four months between March - June 2018. In the frame of United Nations International Children's Emergency Fund and Business Principles collabourating with the Confederation of Turkish Tradesmen and Craftsmen, the program includes 1500 employees and 
managers in ten provinces (Ankara, Adana, Gaziantep, Hatay, İzmir, Malatya, Manisa, Mersin, Ordu and Şanlıurfa) to inform the employers about the child labour. Research sample is realized by 123 persons randomly chosen from for cities (Adana, Mersin, Ordu, Manisa) in the frame of Project universe. The project is carried out with the participated volunteers of NGO leaders who were invited to meetings. 123 participants answered the survey questions about the sociodemographic information form and child labour. Child Rights Attitude Scale (QMACR) is applied to the participants before and after the training.

\section{The Training Module}

The training module is launched out to prevent child labour, to support the children and families, to raise consciousness of employers on child labour, to monitor child worker via workplace based mechanisms, to guide children to social caring system, to direct the children who have potential child worker risks to vocational and technical schools including apprenticeship training center and improve the working conditions of apprentice children. The training module is composed of 16 hours and 2 days. Topics in the module are as following:

- Child labour program

- Child labour: Concept and content

- Current situation of child labour in the world and Turkey

- Legislative regulations on Child Labour

- Children Rights

- Identification and understanding of child workers

- Roles of professional organizations on preventing child labour

- Preventing Child Labour: Facilities that Vocational Training Law provide

- Responsibilities of employers

- Aim, Content and Structure and Functions of IDDG (Current Situation)

- Learning of adults and Attitude Change

\section{Data Tools}

Sociodemographic information form (7 questions), Child labour survey questions (8 questions), Child Rights Attitude Scale are applied to the participants.

\section{Child Labour Survey Questions}

Child labour survey questions are obtained from the ones that take part in the literature (18). The survey is composed of 8 questions based on measuring the perceptions of participants on child labour. One of the choices of participants ("Yes", "No", "I have no idea") is accepted as an answer. 
Questionnaire for Measuring Attitudes towards Children's Rights (QMACR) is improved by Karaman Kepenekçi. ${ }^{13}$ Validity and reliability is realized by Karaman Kepenekçi13; the scale is sole factor, total correlation coefficient varies between 0.32-0.61 and Cronbach Alpha internal consistency coefficient is 0.85, half reliability coefficient is 0.77 . Scale is composed of 22 questions to define participants' attitude on child rights. In 5 point Likert scale the answers are as "Totally agree”, "Agree", "Neutral”, "Disagree” and "Totally disagree". Points are as 1, 2, 3, 4 and 5 and high points got from the scale indicates the negative attitude. 19 of survey questions have positive statements and 3 of them have negative statements; $2^{\text {nd }}, 14^{\text {th }}$ and $15^{\text {th }}$ questions are (across points); total score is between 22-110.

\section{Assessment of Data}

SPSS for Windows 22.0 (Statistical Package for Social Sciences) package program is used for statistical assessment. The relation between the categorical variables is assessed with chi square test. Continuous variables are assessed with Kolmogorov-Smirnov test in the means of normal distribution. Since the normal distribution doesn't supply, Mann-Witney U test is used to compare the average of two groups and KruskalWallis test is used to compare the averages more than two. Pretest and posttest analysis were realized by Wilcoxon test. $\mathrm{p}<0.05$ is accepted as meaningful for all the statistical data.

\section{Ethical Status of the Research}

Research ethics committee approval is acquired from Hatay Mustafa Kemal University (2018/03) and the participants via written and oral.

\section{Restrictions of the Research}

The research is restricted with the samples from 4 provinces; this datum could be used as preliminary data for national and international generalization.

\section{Financial Support}

This research is supported by the Confederation of Turkish Tradesmen and Craftsmen (TESK) and UNICEF.

\section{Results}

According the sociodemographic data of the participants \%65 (80) of them are male and \%35 (43) of them are female. Depending on the age distribution \%3.30 (4) of them are between 18-25 years, \%18.70 (23) of them are between $26-35$ years, $\% 39.80$ (49) of them are $36-45$ years, $\% 38.20$ (47) of them are between $46-56$ years. 
And \%16.30 (20) are elementary school graduate, \%45.50 (56) are high school graduate and \%38.20 (47) are bachelor. \%33.30 (41) of participants are managers and \%66.70 (82) are employees. Depending on the working experience \%17.10 (21) of them are between 0-5 years, \%9.80 (12) of them are between 6-10 years, $\% 73.20(90)$ are 11 years and more experience.

Questions on labour and the distribution of "Yes" response of participants are shown on Table 1. Similar responses are given to the $1^{\text {st }}$ question of Labour survey in the means of gender, age, education and working experience. Depending on the working position distribution, \%31.10 of the managers and \%68.90 of the employers responded as "Yes"; gap between is statically meaningful on behalf of employees ( $p=0.033)$. "Yes" respondents depending on the cities are as \%20.30 from Adana, \%41.90 from Mersin, \%17.60 from Manisa and \%20.30 from Ordu. Gap between is statistically meaningful on behalf of Mersin participants ( $\mathrm{p}=0.032)$. Similar responses are given to the $2^{\text {nd }}$ question of Labour survey in the means of gender, age, working experience, position in the career and cities. Depending on the education level, \%22.60 of elementary school graduates, \%16.10 of high school graduates, \%61.30 of bachelors responded as "Yes"; gap between is statistically meaningful on behalf of bachelors $(p=0.004)$. Similar responses are given to the $3^{\text {rd }}$ question of Labour survey in the means of age, education, working experience and cities. Depending on the gender, \%89.50 of male and \%10.50 of female responded as "Yes; gap between is statistically meaningful on behalf of male (p=0.052). In the means of working position, \%57.90 of managers and \%42.10 of employees responded as "Yes"; gap between is statistically meaningful on behalf of managers $(p=0.041)$. Similar responses are given to the $4^{\text {th }}$ question of Labour survey in the means working position and cities. Depending on the education level, \%19 of elementary school graduate participants, $\% 53.60$ of high school graduate participants and $\% 27.40$ of bachelors responded as "Yes; gap between is statistically meaningful on behalf of graduates ( $\mathrm{p}=0.002)$. Depending on the age distribution, \%2.40 of participants between 18-25 years, 13.10 of participants between 26-35 years, \%40.50 of participants between 36-45 years, \%44 of participants between 46-56 years responded as "Yes"; gap between is statistically meaningful on behalf of participants between 46-56 years ( $\mathrm{p}=0.044)$. Depending on the working experience, distribution is responded as "Yes" around \%17.9 for 0-5 years, \%3.60 for 6-10 years, \%78.60 for 11 and more years; gap between is statistically meaningful on behalf of the ones who have 11 years more working experience $(\mathrm{p}=0.001)$. Similar responses are given to the $5^{\text {th }}$ question of Labour survey in the means gender, age, education, cities and working experience. In the means of working position, $\% 50$ of managers and \%50 of employees responded as "Yes"; gap between is statistically meaningful on behalf of managers $(\mathrm{p}=0.005)$. 
Table 1. Distribution of "Yes" Responses of Child Labour Survey Depending on the Sociodemographic Data

\begin{tabular}{|c|c|c|c|c|c|c|c|c|c|}
\hline & & 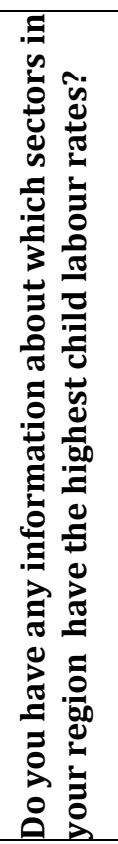 & 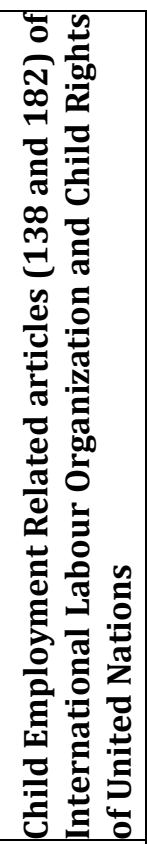 & 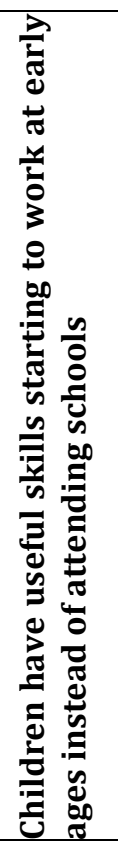 & 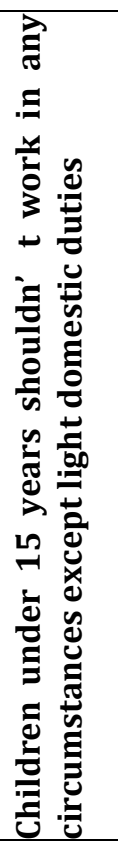 & 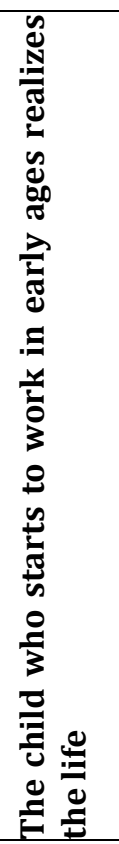 & 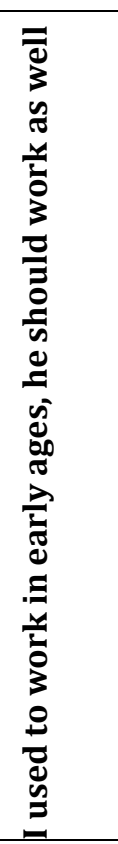 & 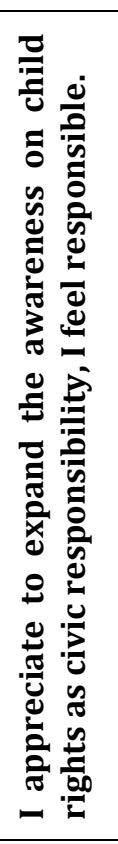 & 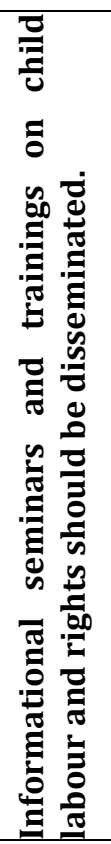 \\
\hline \multirow[t]{3}{*}{ Gender } & Male & 66.20 & 64.50 & 89.50 & 70.20 & 75.00 & 81.00 & 63.50 & 63.20 \\
\hline & Female & 33.80 & 35.50 & 10.50 & 29.80 & 25.00 & 19.00 & 36.50 & 36.80 \\
\hline & p value & 0.231 & 0.611 & $0.052^{*}$ & 0.053 & 0.074 & 0.225 & 0.245 & 0.184 \\
\hline \multirow{3}{*}{$\begin{array}{l}\text { Working } \\
\text { position }\end{array}$} & Manager & 31.10 & 29.00 & 57.90 & 38.10 & 50.00 & 61.90 & 33.90 & 33.30 \\
\hline & Employee & 68.90 & 71.00 & 42.10 & 61.90 & 50.00 & 38.10 & 66.10 & 66.70 \\
\hline & p value & $0.033^{*}$ & 0.293 & $0.041^{*}$ & 0.081 & $0.005^{*}$ & $0.009^{*}$ & 0.812 & 0.741 \\
\hline \multirow[t]{4}{*}{$\begin{array}{l}\text { Working } \\
\text { experience }\end{array}$} & $0-5$ year & 12.20 & 19.40 & 10.50 & 17.90 & 14.60 & 4.80 & 17.40 & 16.20 \\
\hline & 6-10 year & 9.50 & 6.50 & 15.80 & 3.60 & 10.40 & 14.30 & 10.40 & 10.30 \\
\hline & 11-+ year & 78.40 & 74.20 & 73.70 & 78.60 & 75.00 & 81.00 & 72.20 & 73.50 \\
\hline & p value & 0.062 & 0.960 & 0.363 & $0.001^{*}$ & 0.834 & 0.268 & 0.787 & 0.628 \\
\hline \multirow[t]{5}{*}{ Age } & $18-25$ & 2.70 & 6.50 & 5.30 & 2.40 & 2.10 & 0.00 & 3.50 & 2.60 \\
\hline & $26-35$ & 20.30 & 22.60 & 21.10 & 13.10 & 14.60 & 19.00 & 19.10 & 19.70 \\
\hline & $36-45$ & 33.80 & 38.70 & 21.10 & 40.50 & 33.30 & 28.60 & 40.00 & 38.50 \\
\hline & $46-56$ & 43.20 & 32.30 & 52.60 & 44.00 & 50.00 & 52.40 & 37.40 & 39.30 \\
\hline & p value & 0.348 & 0.507 & 0.216 & $0.044^{*}$ & 0.333 & 0.573 & 0.956 & 0.236 \\
\hline \multirow[t]{5}{*}{ Countries } & Adana & 20.30 & 25.80 & 36.80 & 27.40 & 31.30 & 33.30 & 30.40 & 29.90 \\
\hline & Mersin & 41.90 & 38.70 & 42.10 & 32.10 & 41.70 & 42.90 & 37.40 & 36.80 \\
\hline & Manisa & 17.60 & 9.70 & 10.50 & 42.40 & 10.40 & 9.50 & 14.80 & 14.50 \\
\hline & Ordu & 20.30 & 25.80 & 10.50 & 33.30 & 16.70 & 14.30 & 17.40 & 18.80 \\
\hline & p value & $0.032^{*}$ & 0.721 & 0.227 & 0.066 & 0.522 & 0.810 & 0.001* & $0.009^{*}$ \\
\hline \multirow[t]{4}{*}{ Education } & $\begin{array}{l}\text { Elementar } \\
\text { y school }\end{array}$ & 12.20 & 22.60 & 21.10 & 19.00 & 20.80 & 19.00 & 14.80 & 14.50 \\
\hline & $\begin{array}{l}\text { High } \\
\text { school }\end{array}$ & 16.20 & 16.10 & 57.90 & 53.60 & 54.20 & 52.40 & 47.00 & 46.20 \\
\hline & Bachelors & 41.70 & 61.30 & 21.10 & 27.40 & 25.00 & 28.60 & 38.30 & 39.30 \\
\hline & $p$ value & 0.051 & $0.004^{*}$ & 0.431 & $0.002^{*}$ & 0.198 & 0.883 & 0.507 & $0.046^{*}$ \\
\hline
\end{tabular}


Table 2 Child Rights Scale Points of NGO Leaders before and after the Trainings

\begin{tabular}{|l|l|l|l|l|l|}
\hline & $\mathbf{n}$ & ort & SS & Min-Max & p value \\
\hline Pre-test & 123 & 34.47 & 10.95 & $22-70$ & 0.014 \\
\hline Post-test & 123 & 32.98 & 10.72 & $22-70$ & \\
\hline
\end{tabular}

Wilcoxon test

Table 3 Child Rights Scale Points Depending on the Variables of NGO Leaders

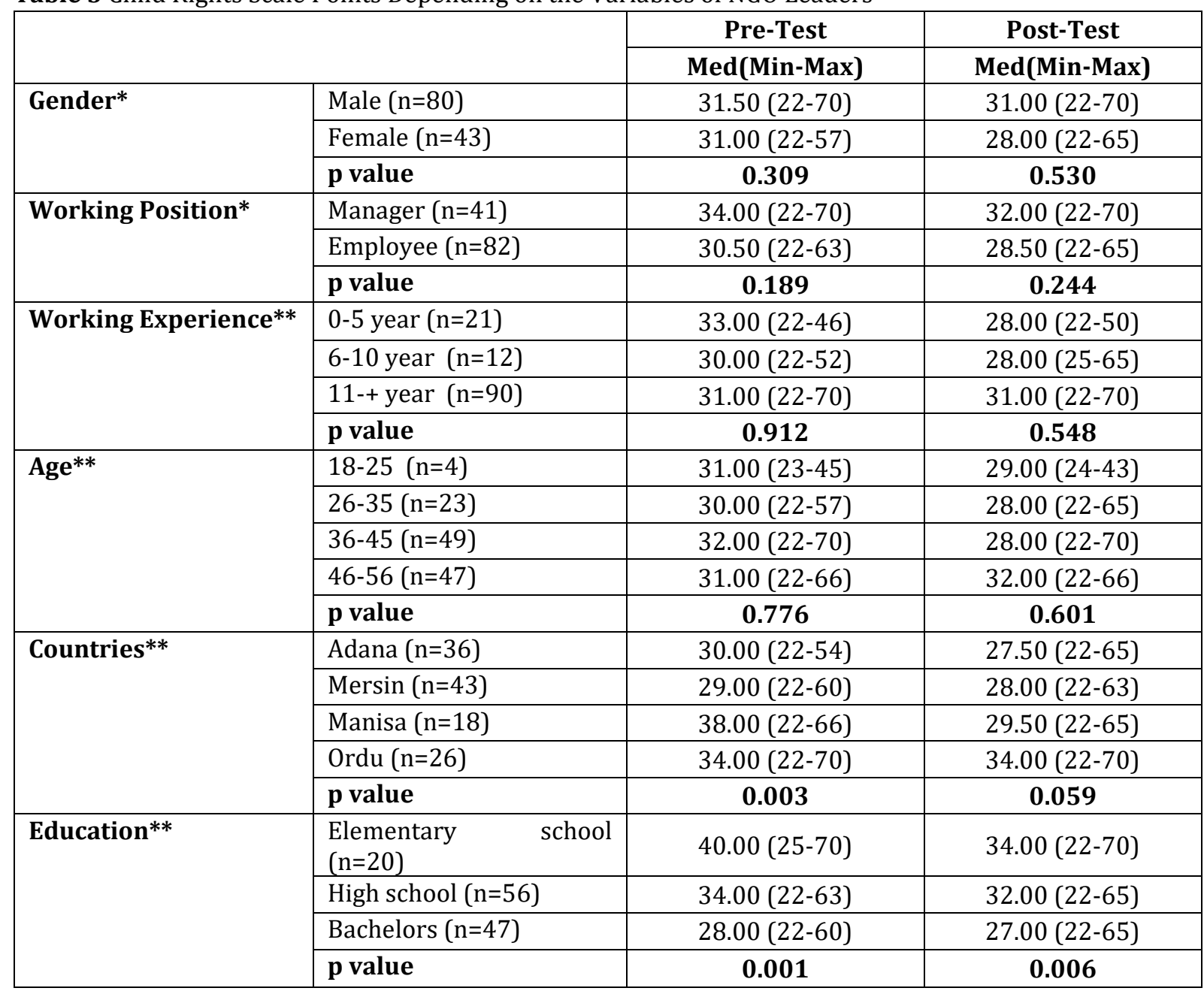

\footnotetext{
*Mann-Witney U
}

** Kruskal-Wallis $\mathrm{H}$

Similar responses are given to the $6^{\text {th }}$ question of Labour survey in the means gender, age, education, cities and working experience. In the means of working position, \%61.90 of managers and \%38.10 of employees responded as "Yes"; gap between is statistically meaningful on behalf of managers $(\mathrm{p}=0.009)$. Similar responses are given to the $7^{\text {th }}$ question of Labour survey in the means gender, age, working experience, working position 
and education. Depending on the cities, \% 30.40 of "Yes" respondents are from Adana, \%37.40 of them are from Mersin, \%14.80 of them are from Manisa, \%17.40 of them are from Ordu; gap between is statistically meaningful on behalf of Mersin participants $(\mathrm{p}=0.001)$. Similar responses are given to the $8^{\text {th }}$ question of Labour survey in the means gender, age, working experience, working position. Depending on the cities, \%29.90 of "Yes" respondents are from Adana, \% 36.80 of them are from Mersin, \%14.5 of them are from Manisa, \%18.80 of them are from Ordu; gap between is statistically meaningful on behalf of Mersin participants ( $\mathrm{p}=0.009)$. Depending on the education level, \% 14.50 of elementary school graduates, \%46.20 of high school graduates, \%39.30 of bachelors responded as "Yes"; gap between is statistically meaningful on behalf of bachelors $(\mathrm{p}=0.046)$ (Table 1).

Depending on the data of Questionnaire for Measuring Attitudes towards Children's Rights (QMACR), pre-test points average is $34.47 \pm 10.95$, post-test is defined as $32.98 \pm 10.72$; gap between is statistically meaningful $(p=0.014)$ (Table 2). QMACR data of the research depending on the sociodemographic data is shown in Table-

3. There is no difference between the pre-test and post-test points of participants depending on the gender, working position, working experience distribution $(\mathrm{p}>0.05)$. Depending on the cities, QMACR pre-tests are statistically meaningful on behalf of Mersin $(p=0.003)$ and positive decrease is noticed on QMACR post-test points but there is no meaningful difference between the cities ( $p>0.05)$. Depending on the education level, QMACR point average for elementary school graduates is $40.00 \pm 13.60$, for high school graduates is $34.00 \pm 9.82$, for bachelors is defined as $28.00 \pm 10.71(\mathrm{p}<0.001)$. In advanced analysis, statistical gap is meaningful on behalf of university bachelors ( $\mathrm{p}<0.001)$, statistical gap is meaningful on behalf of university bachelors on post-tests as well $(\mathrm{p}=0.006)$ (Table 3).

\section{Discussion}

The participants from the NGO's in this research experienced a children rights-based approach to education, while learning about children rights on child labour. According to the data of the NGO participants on labour survey, most of the responses given were similar in the means of gender, age, education, working experience and working position. It is understood that the participants' sociodemographic background effect their opinions on child labour. The study of Khatab, Raheem ${ }^{14}$ revealed a significant influence of socio-demographic effect on child labour and violence against children in Egypt also. ${ }^{14}$ The other study emphasizes that sensitivity to the economic and cultural context is important in understanding child labour and practices that are in the best interests of the child. ${ }^{15}$ Identification of this issue is essential because it can enable NGO employers to design the working conditions in a better manner in order to target the issue for solution. Sum literature results show that the structural and legal barriers of NGO's for realizing children's basic rights should be improved. ${ }^{14,16,17}$ 
The data of QMACR are statistically meaningful between the pre-test and post-test on child labour education from UNICEF Turkey project. This research data demonstrates the success of child labour rights training module. The study of Dunhill ${ }^{17}$ is on the children rights education program and the data gathered shows that the perspectives of the children participating in the research - UNICEF UK - improved as well. Research consistently confirms that rights education program makes a positive contribution to the lives of child labourers. ${ }^{17}$ The study suggested along with the government, different national and international NGO's should take national child protection system monitoring the children's rights achieving a better level via education and health. ${ }^{18}$

QMACR points of bachelor NGO participants are better than other education levels in this study. These points in the pre-test in our study are changed in regional cities. According to the similar research, the regional effect suggests the need to give more attention to some cities that have high rates of child labour. ${ }^{14}$ Children's rights as all moral standards are limited to a particular cultural tradition. However, it is necessary to recognize that children around the world face very different cultural, social and economic environments along childhood including child labour. ${ }^{15}$ The study of Beazley ${ }^{19}$ which is accomplished in a different region explained that child labour is an important issue for child rights activists as it is regarded as informal labour. The Ministry of Labour in Indonesia does not monitor the informal sector; it is not included in the country's labour laws. ${ }^{19}$ There is still need to understand regional differences about child rights and clarify their - both positive and negative experiences from their own perspective in other countries.

The United Nations Convention on the Children Rights offers special protection for Children that they shouldn't need to defend themselves. Child health professionals need to act as advocates in order to protect the most vulnerable in society. Reducing child labour and its impacts on children is morally and legally the right thing to do. ${ }^{20}$ Finally, the research outlines how child health professionals can take action by supporting policies to reduce child labour, providing services that increase consult child rights legislation during child labour and understanding the problem and assessing the impact of action.

\section{References}

1. Waterston T, Davies R. The Convention on the Rights of the Child. Lancet. 2006;367(9511):635.

2. Waterston T, Yilmaz G. Child Rights and Health Care: International Society for Social Pediatrics and Child Health (ISSOP) Position Statement. Child: care, health and development. 2014;40(1):1-3.

3. Tisdall E K M. Children's Rights and Children's Wellbeing: Equivalent Policy Concepts? Jnl Soc Pol. 2015;44:807-23.

4. Raman S, Woolfenden S, Williams K, Zwi K. Human rights and child health. Journal of paediatrics and child health. 2007;43(9):581-6.

5. UN. On World Day Against Child Labour, UN urges protection for children in conflicts and disasters. https://news.un.org/en/story/2017/06/559252-world-day-against-child-labour-un-urges- 
protection-children-conflicts-and2017 [updated https://news.un.org/en/story/2017/06/559252world-day-against-child-labour-un-urges-protection-children-conflicts-and24/07/2019].

6. UN. Fight against child labour moving in right direction, but not quickly enough - UN report. https://news.un.org/en/story/2013/09/4498122017 [24/07/2019].

7. Foroughi M, Moayedi-Nia S, Shoghli A, Bayanolhagh S, Sedaghat A, Mohajeri M, et al. Prevalence of HIV, HBV and HCV among street and labour children in Tehran, Iran. Sex Transm Infect. 2017;93(6):421-3.

8. Iacobucci G. Labour promises healthier food for children and standardised tobacco packaging. Bmj. 2015;350:h268.

9. Zainab S, Kadir M. Nutritional status and physical abuse among the children involved in domestic labour in Karachi Pakistan: a cross-sectional survey. Journal of the Pakistan Medical Association. 2016;66(10):1243-8.

10. Karimi-Sari H, Rezaee-Zavareh MS, Alavian SM. Street and labour children; special group for elimination of viral hepatitis in Iran. Sex Transm Infect. 2017;93(1):38-.

11. Houben E, Smits E, Pimenta JM, Black LK, Bezemer ID, Penning-van Beest FJ. Increased risk of morbidities and health-care utilisation in children born following preterm labour compared with fullterm labour: A population-based study. Journal of paediatrics and child health. 2019;55(4):446-53.

12.Zwi K, Chaney G. Refugee children: rights and wrongs. Journal of paediatrics and child health. 2013;49(2):87-93.

13. Karaman Kepenekçi Y. A study of university studets' attitudes towards children's rights in Turkey. . The International Journal of Children's Rights. 2006;14:307-19.

14. Khatab K, Raheem MA, Sartorius B, Ismail M. Prevalence and risk factors for child labour and violence against children in Egypt using Bayesian geospatial modelling with multiple imputation. Plos One. 2019;14(5).

15. Adonteng-Kissi O. Parental perceptions of child labour and human rights: A comparative study of rural and urban Ghana. Child Abuse Neglect. 2018;84:34-44.

16. Qi D, Wu YC. The extent and risk factors of child poverty in urban China - What can be done for realising the Chinese government goal of eradicating poverty before 2020. Child Youth Serv Rev. 2016;63:74-82.

17. Dunhill A. Does teaching children about human rights, encourage them to practice, protect and promote the rights of others? Educ 3-13. 2018;46(1):16-26.

18. Hakim A, A. R. Health and Nutritional Condition of Street Children of Dhaka City: An Empirical Study in Bangladesh. Science Journal of Public Health. 2016;4(1):6-9.

19. Beazley H. Multiple identities, multiple realities: children who migrate independently for work in Southeast Asia. Child Geogr. 2015;13(3):296-309.

20. Wickham S, Anwar E, Barr B, Law C, Taylor-Robinson D. Poverty and child health in the UK: using evidence for action. Arch Dis Child. 2016;101(8):759-66. 